\title{
Didaktik i integrativa \\ lärarprofessionsämnen
}

\author{
Jesper Sjöström, bitr. professor, jesper.sjostrom@mau.se \\ Fakulteten för lärande och samhälle, Malmö universitet
}

\begin{abstract}
Resumé
Artikeln diskuterar vad ämnesdidaktik (på danska: fagdidaktik) är och kan vara och presenterar ett ramverk för didaktik i integrativa lärarprofessionsämnen. I de senare undervisas ämneskunskaper integrerat med kunskaper för lärarprofessionen, främst didaktik. Ramverket, som utvecklats med inspiration från Klafkis didaktiska analys, består av tio analysområden för att utveckla ämnesdidaktiken inom olika lärarprofessionsämnen. Analysområdena kan även användas som vägvisare för den ämnesdidaktiska forskningen, som är olika utvecklad inom olika ämnesområden. Aktiv didaktisk forskning är nödvändig för att åstadkomma forskningsbaserade lärarutbildningar. I slutet av artikeln presenteras några sammanfattande tankar kring professionsdidaktik för blivande lärare och vilka implikationer det får för lärarutbildarnas kompetensutvecklingsbehov.
\end{abstract}

Nøgleord (svenska): lärarutbildning, integrativ didaktik, professionsdidaktik, allmän ämnesdidaktik, didaktisk praxis, didaktisk forskning

Nøgleord (dansk): læreruddannelse, integrativ didaktik, professionsdidaktik, almen fagdidaktik, didaktisk praxis, didaktisk forskning

\section{Introduktion}

Malmö universitet har en drygt 15 år lång historia av särskilda lärarprofessionsämnen där ämneskunskaper i lärarutbildningarna integreras med ämnesdidaktik (på danska: fagdidaktik), allmändidaktik och även i viss mån med pedagogik (Holmberg, 2008). Lärarutbildningarna är professionsutbildningar som behöver en professionsrelevant forskningsbas. Rektorn för dåvarande Lärarhögskolan i Malmö, Olle Holmberg, tog i början på 2000-talet initiativ till det som från början kallades huvudämnen och som 
numera benämns akademiska lärarprofessionsämnen. Det är "kunskapsfält, där utveckling och forskning sker och där lärarutbildarens kompetens är självklar och oomtvistad" (Holmberg, 2008, s. 61). Malmö universitet har kommit en bra bit på vägen, samtidigt som det finns en hel del kvar att utveckla både vad gäller forsknings- och praktikförankring och vad gäller integrationen mellan ämnesstudier och studier i utbildningsvetenskap. Den här artikeln lyfter frågor kring vilket kunskapsinnehåll som behövs i sådana integrativa lärarprofessionsämnen utformade utifrån blivande lärares behov. Ett centralt inslag är didaktik, som - förutom undervisningskonst - kan sägas vara namnet på lärarnas professionsvetenskap (Hansén \& Forsman, 2017; Jakobsson, Lundegård \& Wickman, 2014). Hansén och Sjöberg (2006, s. 270) skrev redan för drygt tio år sedan att didaktiken är "lärarutbildningens fundament och kärna. I didaktiken förenas [...] pedagogik/didaktik och ämne i teori och praktik".

Samtidigt skrev Nilholm (2016, s. 157) nyligen att det är "långt kvar till att flertalet studenter som ska bli lärare inom områden/ämnen kan förvänta sig att finna en didaktisk forskningsöverbyggnad för detta vid lärosätena." I stor utsträckning handlar det om att lärarhögskolorna inte prioriterat didaktisk forskningskompetens, men även om att olika ämnesdidaktiska forskningsområden är olika långt komna forskningsmässigt. Dessutom betonas ämnesinnehåll och metodik olika mycket i olika ämnesdidaktiska forskningstraditioner (Brantefors, 2016). Sammantaget är ämnesdidaktik ett omfattande och komplext område med flera olika traditioner som lever jämsides och delvis är inflätade i varandra (Sjöholm m.fl., 2017).

En utgångspunkt i denna artikel är därför det som jag benämner allmän ämnesdidaktik (Sjöström, 2016; 2017; redan för femton år sedan använde Steffensen, 2003, termen "almen fagdidaktik"; se även t.ex.: Ongstad, 2006; Kansanen, 2009; Wickman, 2012). Det har många likheter med så kallad komparativ ämnesdidaktik (på danska: sammenlignende fagdidaktik) (se t.ex. Nielsen, 2011; Ligozat, Amade-Escot, \& Östman, 2015), där det med "utgångspunkt i angreppssätt och resultat från studier inom didaktikens olika fält görs jämförelser och analyser som syftar till att skapa generell kunskap om undervisning, undervisningsinnehåll, lärande och socialisation" (Almqvist, 2016, s. 4-5). Det handlar alltså om en ämnesdidaktisk metanivå, där olika ämnesdidaktiska områden jämförs och kan lära av varandra. I linje med detta skriver Öhman (2014, s. 35): "Jag ser didaktiken som en gemensam spelplan för de ämnen som är involverade i lärarutbildning och menar att didaktiken kan fungera som sammanlänkande begrepp mellan ämnena". Den vetenskap- 
liga didaktiken kan lägga grunden för ett professionellt språkbruk (Hansén \& Sjöberg, 2006).

Allmän ämnesdidaktik kan även peka på forskningsfrågor/områden där ett visst ämnes didaktik är i behov av forskning och utveckling. I denna artikel presenterar jag en lista med tio analysområden som kan ses som ett ramverk för forskningsbaserad ämnesdidaktik i integrativa lärarprofessionsämnen. Listan kan även användas för att identifiera forskningsluckor inom ett visst ämnesdidaktiskt forskningsområde. Som en bakgrund till listan beskriver jag först lärarkunskap i allmänhet, för att därefter komma in på (ämnes) didaktik som lärares centrala professionskunskap.

Genomgående bygger artikeln på omfattande litteraturstudier av såväl allmän- och ämnesdidaktisk litteratur som läroböcker och annan relaterad forskningslitteratur. Flera exempel är hämtade från naturvetenskapernas didaktik, eftersom det är mitt didaktiska specialområde.

\section{Vilka kunskaper behöver lärare?}

En lärare behöver såväl teoretiska som praktiska kunskaper i pedagogik i bred bemärkelse och skolrelevanta ämneskunskaper. Dessutom behöver hen ämnesdidaktiska kunskaper. Shulman (1987) var tidigt ute med att diskutera vilka kunskaper en lärare behöver. Olika etiketter har satts på dessa, men Wickman och Persson (2015, s. 14) har gjort följande inledning:

- ämneskunskaper

- allmänna pedagogiska kunskaper

- kunskaper i metodik

- kunskaper i lärande

- kunskaper i skolans organisation

- kunskaper i skolans värdegrund

- didaktiska kunskaper [i en smal bemärkelse; se vidare nedan]

Senare har det gjorts ett antal tolkningar, utvidgningar och preciseringar av Lee Shulmans Pedagogical Content Knowledge (PCK) (se t.ex. Berry, Friedrichsen \& Loughran, 2015). Ekendahl, Nohagen och Sandahl (2015) sammanfattar lärarkunskapen i ämneskunskaper, undervisningsförmåga och social kompetens. Vidare skiljer de i sin didaktikmodell mellan en abstrakt nivå med didaktiska principer/reflektioner och där varför-frågan är övergripande - och en konkret nivå - med didaktisk handlingskompetens. I den didaktiska praktiken spelar värden och teorier en stor roll, men även olika oförutsedda 
omständigheter. Utöver lärarkunskapen för själva undervisningen behöver lärare kunskaper om det omgivande samhället (det vill säga kunskaper bl.a. i skolans organisation och värdegrund). Det brukar kallas för en utvidgad didaktisk triangel (se t.ex. Wahlström, 2015). Brante (2016, s. 57) lyfter fram didaktikens - jämfört med många andra vetenskapliga ämnens - "komplexa koppling mellan teori och praktik", och Bronäs och Runebou (2016) betonar den filosofiska grunden. Krogh, Qvortrup och Spanget Christensen (2016, s. 75) skriver: "Didaktik betegnes som en vidensform, der både knytter an til praksis, som den dog tilstræber en vis afstand til, og til videnskabelig viden, som den søger at tilnærme sig".

\section{(Ämnes)didaktik som lärares centrala professionskunskap}

Föga förvånande finns det flera olika tolkningar av vad ämnesdidaktik är för någonting. Brante (2016) pekar på dels en mycket bred definition, där"allt som har med undervisningen av ett visst ämne att göra är ämnesdidaktik" (s. 55), dels en betydligt snävare syn där man närmast sätter "likhetstecken mellan ämneskunskaper och ämnesdidaktik" (s. 56). Dessutom finns som sagt inom begreppet en spänning mellan teori och praktik (Jank \& Meyer, 1997). I figur 1 har jag försökt fånga in dessa synsätt genom ett Venndiagram som beskriver integrativa lärarprofessionsämnen som mötet mellan ämne, utbildningsvetenskap och undervisningspraktik. Med en bred definition av ämnesdidaktik kan den inkludera allt från skolrelevanta ämneskunskaper (i och om), via ämnes- och lärarutbildningsrelevant utbildningsvetenskap (främst didaktik), till praktiska kunskaper relaterade till undervisning i det aktuella ämnet (ämnesmetodik). Samtidigt utgör forskningsreflekterad praktik den ämnesdidaktiska kärnkunskapen (den yta i mitten där de tre cirklarna överlappar varandra). Gundem (2008, s. 1) skriver: "Det er i skjæringspunktet mellom pedagogisk teori og fagvetenskap, mellom allmenn didaktisk teori og opplæringsverkeligheten, at fagdidaktiske overveielser finner sted". 


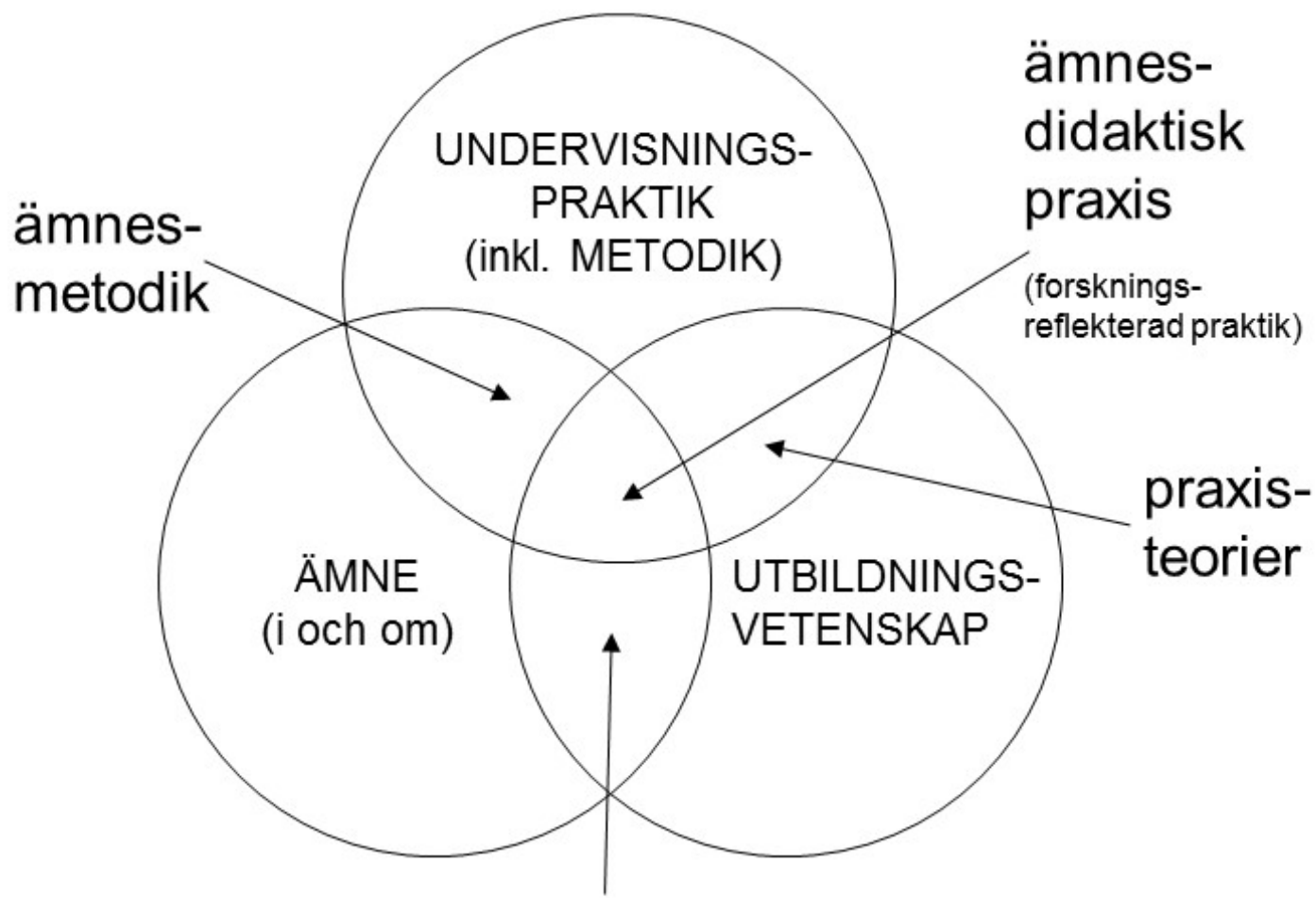

\section{forskningsbaserad ämnesdidaktik}

Figur 1. Venndiagram för att beskriva innehållet $i$ integrativa lärarprofessionsämnen.

Den stora spännvidden i tolkningen av vad som är ämnesdidaktik gör att det finns flera olika typer av ämnesdidaktisk kurslitteratur. Jag ska lyfta fram några exempel, först på några böcker som tar ett helhetsgrepp kring ämnet och som kan sägas utgöra bred ämnesdidaktisk litteratur, och sedan ett exempel på en smal bok med ett betydligt snävare fokus. Därefter lyfter jag, efter ett problematiserande avsnitt, fram några exempel på ämnesdidaktisk litteratur som ligger någonstans däremellan.

\section{En bred syn på ämnesdidaktik}

Jag börjar med att beskriva några ämnesdidaktiska läroböcker som placerar in skolämnet i ett vidare sammanhang och även diskuterar implikationer för undervisningspraktiken. Ett särskilt föredömligt exempel är Håkan Larssons (2016) Idrott och hälsa - i går, i dag, i morgon. Den placerar in det svenska skolämnet idrott och hälsa i såväl historiska och socio-politiska som pedago- 
giska och praktiknära sammanhang. Den innehåller även kritiska perspektiv i form av exempelvis ett kapitel kring normkritisk undervisning. Vidare förhåller den sig till frågor om upplägg och forskningsbasering av idrottslärarutbildningen i ett senmodernt samhälle. Med en bred syn på ämnesdidaktik inkluderas även exempelvis ämnets roll och användning i samhället och hur det kommuniceras i olika medier.

Tre andra exempel på breda ämnesdidaktiska läroböcker, som kan sägas vara skriva utifrån en humanistisk ansats, är: Undervisa $i$ samhällskunskap - en ämnesdidaktisk introduktion (Ekendahl, Nohagen \& Sandahl, 2015), Historieundervisningens byggstenar - grundläggande pedagogik och ämnesdidaktik (Hermansson Adler, 2009) och Naturvetenskap som allmänbildning - en kritisk ämnesdidaktik (Sjøberg, 2010). Alla dessa kan ses som exempel på "flervetenskaplig ämnesdidaktik" (Ongstad, 2006).

Av de nämnda böckerna tycks dock Sjøbergs (2010) bok vara ensam om att lyfta frågan om ämnesövergripande undervisning. Exempelvis har undervisning kring samhällsfrågor med naturvetenskapligt innehåll under senare år vuxit fram som en viktig del av forskningen inom naturvetenskapernas didaktik (Ekborg m.fl., 2016). Sjøbergs bok innehåller även i viss utsträckning miljöperspektiv, men ingen av de nämnda böckerna behandlar hållbarhetsperspektiv på ett mer övergripande sätt. Detta tycks lämnas till särskilda ämnesövergripande böcker i miljö- och hållbarhetsdidaktik, såsom den numera klassiska Miljödidaktik - naturen, skolan och demokratin (Sandell, Öhman \& Östman, 2003) och den nya Hållbar utveckling - ämnesdidaktisk tematisering för grundskolan (Sund \& Sund, 2017).

\section{En snäv syn på ämnesdidaktik}

Ett talande exempel på en extremt smal ämnesdidaktisk lärobok är Milstolpar och fallgropar i matematikinlärningen - Matematikdidaktisk teori om misstag, orsaker och åtgärder av Bentley och Bentley (2016). Den saknar helt humanistisk, samhällelig och allmänpedagogisk kontext och går, efter en mycket kort beskrivning av hjärnans roll i lärandet, direkt in på olika moment i matematiken som elever har svårt att förstå. I inledningen skriver författarna: "Vi redogör för vanliga misstag och missuppfattningar som kan blockera elevernas fortsatta kunskapsinhämtning" (s. 7). Självfallet kan det vara värdefullt med en systematisk sammanställning av missuppfattningar, men samtidigt är det anmärkningsvärt att författarna inte alls signalerar att boken behöver kompletteras med humanistiskt orienterad matematikdidaktisk litteratur likt Larssons (2016) bok för ämnet idrott och hälsa. Detta särskilt med tanke 
på att man i bokens allra första mening skriver att syftet med boken är "att vägleda lärare i matematikundervisningen" (Bentley \& Bentley, 2016, s. 7). Frågan är då hur mycket ämnesfokus som är önskvärt? I motsats till Brante (2016) menar jag att frågor kring begreppsval, ordning och progression av ämnesinnehåll bör ha en central plats inom ämnesdidaktiken. Vilka nödvändiga begrepp som behövs för förståelse är som jag ser det inte främst ett internt ämnesbekymmer. Det är en fråga för ämnesdidaktiken, som i sin tur kan vägledas av den allmänna didaktikens teorier. Men det är ett stort problem när böcker, såsom den av Bentley och Bentley (2016), utgör sig för att vara ämnesdidaktiska, utan att alls relatera till den pedagogiska och utbildningsvetenskapliga forskningen.

Brante (2016, s. 65) skriver: "Om ämnesdidaktiker på universitet och högskolor [...] tar sin främsta utgångspunkt ifrån ämneskunskaper istället för didaktiska teorier, finns en risk att undervisningsplaneringen blir förenklad"; det "finns en fara att strukturella och kontextuella mekanismer inte uppmärksammas eller problematiseras"; det finns risk att "didaktiskt tänkande kring maktförhållanden, relationer, klassrumsstrukturer och institutionella för givet taganden" försummas. Liknande kritik har tidigare förts fram av bland andra Englund (2007). Samtidigt skriver Sjøberg (2010, s. 35) att man inte kan "lära sig ett ämnes didaktik utan att kunna själva ämnet".

\section{Problematisering av ämnesdidaktik}

När lärarutbildningarna i Sverige år 1977 blev en del av universitet och högskolor, var tanken att en vetenskapligt förankrad didaktik skulle ersätta, eller i alla fall komplettera, metodiken. Förändringarna gick dock långsamt och så sent som 1992 skrev Bra böckers lexikon: "Didaktik är den gren av pedagogiken som behandlar undervisningsmetoderna, vid lärarhögskolorna kallad metodik". Samtidigt ansåg kritikerna att metodikämnet grundade sig på "att skickliga lärare delade med sig av sina erfarenheter av undervisning" (Almqvist, 2016, s. 2). Det gjorde inriktningen instrumentellt inriktad, snarare än att vara reflekterande och problematiserande. På liknande sätt har Englund (2007) hävdat att även didaktikbegreppet blivit belastat av en icke-problematiserande syn på undervisning: "Didaktikbegreppet tenderar ofta att representera [...] den tämligen traditionella synen på undervisning och lärande" (s. 2), och Wello Westlin (2000, s. 91) varnar för att "den praktiskt inriktade didaktiken inom lärarutbildningen löper risk att legitimera förgivettaganden beträffande ämnesinnehållet om de inte problematiserar detta innehåll". Det är här som den ämnesdidaktiska forskningen kan spela 
en central roll. För att bli relevant behöver den knyta an till sina samtliga tre baser: ämnesinnehållet, undervisningspraktiken och utbildningsvetenskapliga teorier (inkl. kritiska perspektiv).

\section{Ämnesdidaktisk medelväg}

Då det gäller ämnesinnehållet kan den ämnesdidaktiska forskningen handla om exempelvis ämnesprogression (se t.ex. Talanquer, 2018) och om olika svar på de didaktiska vad- och hur-frågorna. Anderssons (2008a; 2008b; 2011) ämnesdidaktiska trilogi utgör exempel på läroböcker där ämnesdidaktiken främst handlar om ämnesinnehåll, progression, begreppsförståelse och/eller metodik. Han behandlar relevant ämnesinnehåll, såsom "system jorden", människan och klimatet respektive naturvetenskapliga arbetssätt. Vidare betonar han ämnesintegration och samspelet natur-teknik-samhälle (Andersson, 2008a). I trilogins sista bok finns avsnitt om bland annat naturvetenskapens karaktär, den didaktiska varför-frågan, lärarrollen, lärande, språkperspektiv och didaktisk design (Andersson, 2011).

För de tidigare skolårens lärare har Areskoug och Ekborg med medförfattare skrivit ännu mer ämnesnära böcker med utgångspunkt från naturvetenskapens bärande idéer (Areskoug m.fl., 2013; Areskoug m.fl., 2015), varav den senare boken är helt inriktad på metodik. I Finland talar man för grundlärare (med elever i åldern 7-12 år) om "didaktisk ämnesteori" (Hansén \& Sjöberg, 2006).

Sammantaget kan man alltså närma sig ämnesdidaktik från tre olika håll: från ett ämneshåll, från praktikens (den beprövade erfarenhetens) håll och från pedagogikforskningens håll. Brante (2016) är en typisk representant för det senare synsättet. Jag är benägen att instämma i större delen av hans oro och kritik, men tycker samtidigt att han missar ett viktigt fokus på att ämnesdidaktiken behöver förankring i såväl ämneskunskaper som i praktiken, utöver en bas i utbildningsvetenskaplig/didaktisk teori (se figur 1 igen). Jag menar att ämnets kontextuella helhet är en central del av den ämnesdidaktiska kunskapen, likväl som att en problematisering av skolämnesinnehållet och hur det kan och bör undervisas är det. Den ämnesdidaktiska forskningen får inte stanna vid konstateranden, utan behöver även diskutera implikationer och alternativ för didaktisk praxis. 


\section{Klafkis didaktiska frågor pekar mot en integrativ didaktik}

Naturligtvis finns det inte endast ett svar på vad som är relevant ämnesinnehåll, men här tar jag stöd av Wolfgang Klafki och hans didaktiska analys. Klafkis (2000) didaktiska tänkande utgick ifrån sådan bildning (på danska: dannelse) som fritänkande, medvetna och solidariska medborgare behöver i ett demokratiskt och hållbart samhälle (se även t.ex. Kemp, 2005; Sjöström, 2018a). Han identifierade två huvudtankar kring bildning. Den första kallas materialbildning och i den prioriteras innehållskunskap framför allmänna förmågor. Den andra inriktningen kallas formalbildning och i den prioriteras personlighetsutveckling före faktakunskaper. Generellt förordade Klafki formal- framför materialbildning, samtidigt som han lyfte fram att det alltid måste finnas ett ämnesinnehåll att förhålla sig till. En integrerad bildningssyn, som baseras på både formal- och materialbildning, kallade han för kategorial bildning. Med en sådan blir urvalet av ämnesinnehåll viktigt och det gäller för läraren att arbeta utifrån en "exemplarisk princip", där hen väljer innehåll utifrån vad som är representativt, väsentligt och relevant. Klafki förespråkade fokus på ämneskunskaper som är relevanta i relation till utvecklingen av var och ens demokratiska och solidariska förmågor (Midtsundstad \& Willbergh, 2010, särskilt Birkeland, 2010).

Klafkis så kallade didaktiska analys bygger på fem frågeområden som syftar till att tydliggöra den aktuella ämneskunskapens relevans och struktur och hur läraren kan begripliggöra den för eleverna (Hopmann, 1997; Klafki, 1997; Sjöström, 2018a). Exempel på för vår tid epoktypiska nyckelproblem är klimatfrågan och migrationsfrågan, för att nämna ett par exempel på frågor som uppkommit i möten mellan samhällsutveckling, teknik, ekonomi och miljö. Det handlar alltså med andra ord om hållbarhetsfrågor. Utifrån ett sådant synsätt blir utgångspunkten i undervisningen frågor och ämnesinnehåll som är relevanta för ungdomarna och samhället, nu och i framtiden. I linje med detta har Fritzell och Fritzén (2007) föreslagit integrativ didaktik som ett sätt att koppla samman fokus på ämneslärande med tydliga värdegrundsperspektiv såsom bildning och demokratisk fostran. De menar att integrativ didaktik tar sin utgångspunkt i praktiken, men inte med en snäv ämnesinriktning, utan med helhetsinriktning och kritisk teoretisering.

En integrativ didaktik har potential för förhållningssätt som bygger broar mellan de didaktiska frågorna, olika ämnen, teori-praktik, bildning-nytta etc. Samtidigt behöver den tolkas, preciseras och beforskas i olika ämnes-, stadie- och lärandekontexter. Därför behövs olika specialiseringar inom 
didaktiken. Didaktikforskning görs för lärare och utförs oftast av lärarutbildade forskare. Många gånger görs den med lärare i praxisnära forskningsprojekt. Utgångspunkten är lärarnas behov, både de behov som de själva upplever och de behov som didaktikforskarna får syn på i möten med praktiken.

\section{Tio analysområden för att utveckla ämnesdidaktiken i integrativa lärarprofessionsämnen}

Med inspiration av Klafkis frågeområden kring undervisningsinnehållet, men nu med fokus på professionsdidaktik för blivande lärare, förslår jag tio analysområden (se uppställning nedan) som kan användas vid utveckling av det ämnesdidaktiska innehållet $\mathrm{i}$ integrativa och bildningsorienterade lärarprofessionsämnen. Analysområdena kan även användas som vägvisare för den ämnesdidaktiska forskningen.

Det är jag som är upphovsman till de tio analysområdena, men flera kollegor vid Malmö universitet kom med värdefull input under de två år som ramverket arbetades fram. I maj 2015 ansvarade jag för ett fakultetsgemensamt seminarium på temat "ämnesdidaktisk kärna". När jag förberedde mig inför seminariet formulerade jag en första version av de ämnesdidaktiska analysområdena. I början på 2016 höll jag en workshop på temat "didaktik, ämnesdidaktik och metodik" för några av fakultetens lärarutbildare, och under 2017 hade jag ett fakultetsuppdrag avseende ämnesdidaktik i ämneslärarutbildningen vid Malmö universitet. De tio analysområdena formulerade jag under våren 2017.

Två viktiga utgångspunkter vid formulerandet av analysområdena var relevans och forskningsbasering. Förutom kunskaper $i$ ämnet, behöver läraren kunskaper om ämnet/ämnesområdet (analysområde 2). Hen bör även ha en grundläggande förståelse för vad ämnesdidaktisk forskning är för någonting (analysområde 1). En annan utgångspunkt är en bred syn på ämnesdidaktik, där skolämnet/ämnesområdet kontextualiseras utifrån flera olika perspektiv (analysområde 3 och 4). Vidare är det självklart viktigt att förhålla sig till elevers och lärares relation till skolämnet (analysområde 5 och 6) och att på djupet förstå skolämnets gängse undervisningspraktik (analysområde 7), men även möjliga alternativa didaktiska val (analysområde 8). Till det kommer värdegrundperspektiv och liknande (analysområde 9) samt en teoretisk fördjupning i (ämnes)didaktik (analysområde 10). 
I tabell 1 preciserar jag innehållet i de tio analysområdena genom ett antal frågor. Dessa frågor tillsammans med analysområdets rubrik är i stor utsträckning självförklarande, men för att ändå ytterligare tydliggöra så finns nedan beskrivningar av respektive analysområde, med exempel hämtade från främst naturvetenskapernas didaktik.

Tio analysområden för utveckling av ämnesdidaktik i integrativa lärarprofessionsämnen.

\begin{abstract}
Ämnesdidaktisk forskning: Hur ser den ämnesdidaktiska forskningen ut i ämnesområdet? Vilka är de centrala ämnesdidaktiska idéerna/teorierna/modellerna? Vilka ämnesdidaktiska läromedel finns tillgängliga? etc.
\end{abstract}

Metaperspektiv på ämnet: Vilken karaktär har det (akademiska) ämnet? Hur är det indelat? Vilka arbetssätt har det? Hur ser ämnets kunskapskulturer ut? Vilken roll har ämnet i relation till andra (akademiska) ämnen? Vilken roll har ämnet i samhället? Vilken roll har ämnet i relation till globala utmaningar och hållbarhetsfrågor? etc.

Metaperspektiv på skolämnet: På vilka sätt skiljer sig skolämnet från det rena/akademiska ämnet? Vilken struktur har skolämnet? Hur delas det in? Vilka olika intressen har format skolämnet? Vilken roll har ämnet i relation till andra skolämnen? Vilken kunskapsprofil har skolämnet? Hur ser dess natur ut? etc.

Skolämnets kultur och traditioner: Vilka kunskapskulturer har skolämnet? Vilka kopplingar finns till olika bildningsideal och läroplansfilosofier? Vilka så kallade selektiva traditioner finns? etc.

Elevers relation till ämnet: Hur ser elevers intressen, attityder, rädsla, föreställningar och förståelse ut i relation till ämnesområdet? etc.

Lärares/lärarstudenters relation till ämnet: Hur ser lärares/lärarstudenters intressen, attityder, föreställningar, kunskap och förståelse ut i relation till ämnesområdet? Hur svarar de på den didaktiska varför-frågan? Hur ser lärarstudenter och lärarutbildare på lärarprofessionsämnets fördelning mellan ämne och ämnesdidaktik? etc. 


\section{Gängse praxis: undervisning, lärande och bedömning: Vilken är gängse praxis i skolämnet? Hur arbetar ämnet med ämnesbegrepp, vär- deringar, estetik etc.? Hur ser en vanlig fördelning av olika kunskapsem- faser ut? Vilka lärdomar ger samlad beprövad erfarenhet? Hur arbetar ämnet med planering, läromedel, media och bedömning? Hur ser klass- rumskommunikationen i ämnet ut? etc.}

Alternativa didaktiska val: Vilka alternativa visioner/didaktiska program finns beskrivna i forskningslitteraturen? Vilka alternativa arbetssätt/förhållningssätt finns? etc.

Integrativ didaktik: Hur kan ämnet arbeta med allmänna läroplansmål som bildning, demokratisk värdegrund och lärande för hållbar utveckling? Hur kan ämnet arbeta ämnesövergripande? etc.

Didaktisk modellering: Vilka erfarenheter finns inom ämnesområdet av undervisningsutvecklande ämnesdidaktisk forskning baserad på s.k. didaktisk modellering? Hur kan lärare i ämnet stödjas i att arbeta med didaktisk teori och didaktisk modellering? etc.

\section{Ämnesdidaktisk forskning}

Detta analysområde handlar om ämnesdidaktisk forskning. Bronäs och Runebou (2016) hävdar att ämnesdidaktik är en helhet som inte kan delas upp i ämne och pedagogik. De ser ämnesdidaktik som "ett eget vetenskapligt fält med egna frågeställningar" (s. 20) och skriver: "Eftersom både det vetenskapliga ämnet och de didaktiska frågorna är viktiga i studiet av vad ett skolämne är, blir just ämnesdidaktik en adekvat beteckning på detta studium" (s. 100). Allmän ämnesdidaktik står då för de principer och perspektiv som kan tillämpas i olika ämnens ämnesdidaktik.

Wickman och Persson (2015, s. 11) menar att didaktikforskningens "främsta uppgift är att hjälpa lärarna att fatta bättre och bildade beslut om undervisning". Därmed förenas praktik och forskningsfält i en forskningsmedveten undervisningspraktik (praxis). Forskningsfält och praxisfält kan alltså "ses som komplementära och stödjer varandra i en ämnesdidaktisk kunskapsbildning" (Ekendahl m.fl., 2015, s. 173).

Bronäs och Runebou (2016) hävdar att didaktiska teorier "försöker utröna det bästa sättet att leda elever till kunskap" (s. 25). Detta är en normativ 
ingång, medan didaktikforskning kopplad till pedagogik i stället oftast har en deskriptiv ingång. Didaktiken har alltså både en explorativ analyserande funktion (hur ser det ut? - den didaktiska triangeln) och en normativ syntesfunktion (hur kan och bör det se ut? - de didaktiska frågorna). Andersson (2006, s. 207) skriver: "Det är naturligtvis i och för sig av värde att få kunskap om faktiska förhållanden, men minst lika angeläget att skapa, utveckla och undersöka nya innehåll och undervisningssätt som kan föra skolan framåt".

Bronäs och Runebou (2016, s. 22) menar att ämnesdidaktiken bör framhålla didaktiska principer baserade på uttalade mål (t.ex. bildning) och vara handlingsorienterad. De skriver: "Didaktikens grund är [...] till stora delar filosofisk" (s. 23). Empirisk forskning är viktig inom didaktiken, men även filosofisk-hermeneutisk forskning, som resonerar kring målfrågor och utifrån det beskriver implikationer för läraridentitet, undervisning och lärande (se t.ex. Sjöström, 2018b).

Som jag beskrivit ovan så betonar olika ämnesdidaktiska forskningsområden olika aspekter och de är olika långt komna forskningsmässigt. Exempelvis är den historiedidaktiska forskningen i Sverige betydligt mer utbredd och utvecklad än motsvarande didaktisk forskning om samhällskunskapsämnet. Historiedidaktisk forskning i Sverige fokuserar på historiekultur, historiemedvetande och historiebruk (Brantefors, 2016). Den samhällskunskapsdidaktiska forskningen delade Ekendahl m.fl. (2015) nyligen in i följande fyra delar: praxisforskning, socialisationsforskning (kring demokratifostran), läromedelsforskning och läroplansforskning (samspel mellan samhällets ideologi/kunskapssyn och ämnesundervisning). Liknande indelningar kan göras för flera andra ämnesområdes didaktiska fält.

Forskningen i Sverige inom naturvetenskapernas didaktik är mångfacetterad, och det råder ingen egentlig samsyn kring vilka som är ämnesområdets centrala kunskaper. Ändå går det att utifrån exempelvis indelningar av konferenser peka på några nyckelområden: undervisningsforskning, studier av elevers begreppsförståelse, studier av elevers attityder, socio-kulturella-genusrelaterade perspektiv, diskurs- och argumentationsstudier, betydelse av naturvetenskapsämnenas historia, sociologi och filosofi (naturvetenskapens karaktär) i undervisningen, tekniska hjälpmedel (inkl. digitala resurser) i undervisningen, utomhuspedagogik och informellt lärande, bedömningsforskning, naturvetenskaplig allmänbildning och läroplansforskning i bred bemärkelse.

Tyson $(2017 a, b)$ betonar att bildningsmässiga aspekter av ämnesdidaktik inte får försummas till förmån för färdighets- och kunskapsmässiga aspek- 
ter, eftersom man i så fall riskerar att "förlora glädjen inför det som bildning kan vara inom varje ämne, ett sätt att fördjupa sin kännedom om världen och därigenom sig själv (och tvärtom)" (Tyson, 2017a). Men det behöver inte finnas en motsättning mellan bildning och kunskapsutveckling, om man riktar in sig på "dannende undervisning" (Graf, 2017). Ämnesdidaktiska teorier och modeller kan mycket väl utgå från ett sådant synsätt (Vásquez-Levy, 2002; Jank, 2014).

\section{Metaperspektiv på ämnet}

Detta analysområde handlar om att se (det akademiska) ämnet i ett fågelperspektiv. Sjøberg (2010, s. 39) skriver: "Vi behöver kunna se våra ämnen i ett fågelperspektiv, som en del av ett större landskap". Han hävdar att de naturvetenskapliga ämnenas didaktik, förutom att vara baserad på själva ämnena och deras möte med utbildningsvetenskap, även bygger på kunskaper i naturvetenskapernas filosofi och om ämnenas historiska utveckling. Dessutom har man även "nytta av ett [...] sociologiskt perspektiv, både på kunskapen och på dess utveckling" (s. 33). Det handlar om att ha en medvetenhet om de ofta komplexa samspelen mellan naturvetenskap, teknik, samhälle och miljö (Hodson, 2008).

För ett antal år sedan beskrev jag i två artiklar kemiämnet utifrån metaperspektiv. I den ena artikeln diskuterade jag indelningen av kemi och hur det finns både naturvetenskapligt och tekniskt inriktad kemi (Sjöström, 2006a). I den andra artikeln diskuterade jag metakemi och delade in den i följande fem delar: kemifilosofi, kemididaktik (i en smalare bemärkelse), kemihistoria, samhällskemi och grön kemi (Sjöström, 2006b). På motsvarande sätt kan man även för andra ämnen beskriva dem utifrån filosofiska, didaktiska, historiska, samhälleliga och miljömässiga perspektiv. I en bred bemärkelse handlar det om ämnets vetenskapsteori.

Det finns ett helt forskningsfält som studerar naturvetenskaperna och dess forskning utifrån metaperspektiv. På engelska kallas området Science and Technology Studies (Sismondo, 2009). Inom naturvetenskapernas didaktik är sådana perspektiv viktiga inom det breda område som kallas STSE-education (Science, Technology, Society, Environment) (Pedretti \& Nazir, 2011) och som bland annat inkluderar samhällsfrågor med naturvetenskapligt innehåll. Ytterligare ett centralt och relaterat område kallas för Nature of Science (NOS) (McComas, 2017). Det behandlar naturvetenskapernas karaktär och arbetssätt. Angående naturvetenskapernas kunskapskulturer finns det en hel del skrivet, oftast utifrån kritiska perspektiv. Jag har själv problema- 
tiserat kemins gängse diskurser och pekat på alternativa tanke- och handlingssätt (Sjöström, 2007; Sjöström \& Talanquer, 2018).

$\AA$ ena sidan behöver ämnesläraren visa på ämnets identitet, tänkande och kultur. Å andra sidan behöver hen även se det akademiska ämnet med kritisk distans. Aikenhead (2003, s. 125) skriver: "One major challenge for chemistry and physics teachers is to rethink and reformulate their professional identities away from being loyal and accountable to their discipline".

\section{Metaperspektiv på skolämnet}

Detta analysområde handlar om att se på skolämnet utifrån metaperspektiv. En grundläggande utgångspunkt är att skolämnet är skilt från motsvarande akademiska ämne, i större eller mindre utsträckning. Precis som för det akademiska ämnet kan man beskriva skolämnets indelning, filosofi, historia, samhällsrelevans och miljörelevans. Det handlar om skolämnets självförståelse.

En central aspekt för skolämnet är dess möjlighet att bidra till bildning. Detta är även starkt relaterat till den didaktiska varför-frågan. Inom naturvetenskapernas didaktik finns en pågående diskussion kring syftet med naturvetenskaplig allmänbildning. De fyra huvudargumenten handlar om ekonomi, nytta, demokrati och kultur. Sjøberg (2010) argumenterar för att de två senare argumenten är de starkaste. Relaterat till detta finns det mycket skrivet kring det som kallas scientific literacy (se t.ex. Sjöström \& Eilks, 2018), och på liknande sätt finns det inom historiedidaktiken mycket fokus på historiemedvetenhet och historiebruk (Jensen, 2006).

För naturvetenskapsämnena finns det inte så mycket skrivet om vilka olika samhällsintressen som har format skolämnena, men Hultén (2008) har beskrivit ämnenas historia i grundskolan i Sverige. Desto mer finns skrivet kring svenskämnet utifrån ett historiskt perspektiv (se t.ex. Malmgren \& Thavenius, 1991). Angående ämnets relation till andra ämnen så har bland annat Sjøberg (2010), som redan nämnts, diskuterat integrerad naturvetenskaplig undervisning. Han tar dock inte upp så mycket kring språkperspektiv, men det har behandlats mer ingående av andra (t.ex. Olander, 2010). Ytterligare andra intressanta perspektiv handlar om ämnets estetik och miljöorientering.

\section{Skolämnets kultur och traditioner}

Detta analysområde handlar om skolämnets kulturer och traditioner. För miljöundervisning har Sund (2014) beskrivit tre huvudsakliga traditioner: 
(1) den faktabaserade, som fokuserar på naturvetenskapens betydelse för att lösa miljöproblem, (2) den normerande, som fokuserar på förändrad livsstil, och (3) den pluralistiska, som fokuserar på politiska konflikter och demokratifrågor. Sund presenterar även ett reflektionsverktyg som lärare kan använda. Olika undervisningstraditioner kallas generellt för selektiva traditioner och med det menas den undervisning och det innehåll som man av tradition brukar använda sig av (Englund, 2007).

Ett annat intressant perspektiv är skolämnets kunskapsprofil. Den kan beskrivas med hjälp av Roberts så kallade kunskapsemfaser, varav några är den rätta förklaringen, den vetenskapliga metoden, vetenskapens intellektuella process, vardagskontext respektive beslutsfattande (Östman, 2014). Man kan även beskriva skolämnets kunskapsprofil i termer av ämnets fördelning mellan att vara ett kunskaps/kulturämne (epistemologi), ett identitets/upplevelseämne (estetik), respektive ett färdighets/kommunikationsämne (etik) (Ongstad, 2006, s. 112).

\section{Elevers relation till ämnet}

Detta analysområde handlar om elevers relation till skolämnet, inklusive deras kunnande och förståelse. Det kan exempelvis undersökas genom analyser av ämneskonceptioner (Nihlholm, 2016). För de naturvetenskapliga ämnena finns en hel del skrivet kring elevers föreställningar om centrala naturvetenskapliga begrepp (se t.ex. Andersson, 2008b). Det finns även studier om elevers intressen och attityder i relation till naturvetenskap (t.ex. Lindahl, 2003; Jidesjö m.fl., 2009).

\section{Lärares/lärarstudenters relation till ämnet}

Detta analysområde handlar om lärares och lärarstudenters relation till skolämnet. Dels handlar det om deras intressen, attityder, föreställningar, kunskap och förståelse, dels om deras identitet. Det senare är bland annat kopplat till utbildningsfilosofiska synsätt. För naturvetenskapsämnena finns en hel del skrivet om läraridentitet (Avraamidou, 2014). Exempelvis har STSE-undervisning visat sig skapa vissa problem i relation till den gängse naturvetenskapsläraridentiteten (Pedretti, Bencze m.fl., 2008).

\section{Gängse praxis: undervisning, lärande och bedömning}

Detta analysområde handlar om undervisningsämnets gängse praxis och beprövade erfarenheter. Det handlar om en beskrivning av det som Nilholm (2016) kallar "gestaltad didaktik": Hur undervisas ämnet ute i skolorna? Hur 
arbetar man med ämnesbegrepp, värderingar, estetik etc.? Hur ser en vanlig fördelning av olika kunskapsemfaser ut? Vilka lärdomar ger samlad beprövad erfarenhet? Hur arbetar ämnet med planering, läromedel, media och bedömning? Hur ser klassrumskommunikationen i ämnet ut?

Jakobsson, Lundegård och Wickman (2014) är redaktörer för en bok som behandlar allmänna forskningsperspektiv på ämnesundervisning. Boken kan sägas vara en bok i allmän ämnesdidaktik. Den beskriver redskap för att studera och försöka förstå hur det ser ut idag och hur man kan tänka kring alternativa didaktiska val (se vidare nästa analysområde). Några perspektiv som behandlas är exempelvis länken mellan undervisning och lärande (se även: Scott, Mortimer \& Ametller, 2011), lärarens agerande och frågande i klassrummet samt användning av artefakter och olika bedömningspraktiker.

Undervisning i och lärande av ett ämnesinnehåll inbegriper alltid följemeningar, alltså budskap som följer med och som är kopplade till bland annat olika fostransidéer och världsbilder (Östman, 2014). Östman presenterar tre didaktiska typologier: ämnesspråk (typ ämnets språkspel), ämnesfokus (de två huvudfokusen är "introduktion i" och "lära av") respektive kunskapsemfaser (beskrivs ovan i analysområde fyra).

\section{Alternativa didaktiska val}

Detta analysområde handlar om alternativa undervisningspraktiker i ämnet. Om analysområde sju handlade om goda traditioner och beprövade erfarenheter, så handlar detta analysområde om didaktisk förnyelse.

Englund (1997, s. 132) skriver: "Att ett ämnesområde är möjligt att uppfatta på skilda sätt (med olika emfaser) ser jag som central didaktisk kunskap, ideal lärarutbildarkunskap som kan appliceras på de flesta ämnen och ämnesområden". Här finns en tydlig koppling till olika utbildningsfilosofiska inriktningar, såsom essentialism, progessivism och rekonstruktionism. Traditionellt har skolans dominerande tradition varit essentialistisk, det vill säga med fokus på faktaförmedling och att ämnet förenklat blir en miniversion av den bakomliggande akademiska disciplinen. Englund (1997) skriver vidare: "Den didaktiska kompetensen implicerar ett utbildningsfilosofiskt ställningstagande och en beredskap att diskutera utbildningens mål" (s. 140). Det är centralt att lärarna är "medvetna om att det existerar alternativ" (s. 142).

Inom naturvetenskapernas didaktik finns exempelvis beskrivet hur man i undervisningen kan arbeta med kontextbasering (King, 2012), naturveten- 
skapens karaktär (McComas, 2017), samhällsfrågor med naturvetenskapligt innehåll (Ekborg m.fl., 2016), nyhetsmedia (McClune \& Jarman, 2012), handlingskompetens (Bencze \& Alsop, 2014) och Science Centers (Dawson, 2014).

Val av arbetssätt baseras bland annat på utbildningsfilosofisk grundsyn. Olika sådan grundsyn kan i sin tur relateras till olika syn på bildning och litteracitet i ämnet (Sjöström \& Eilks, 2018; Sjöström m.fl., 2017; Sjöström, 2018b). För naturvetenskapsämnena har Stuckey med medförfattare (2013) diskuterat relevansbegreppet. Baserat på bland annat Klafkis idéer lyfter de fram att undervisningen bör vara relevant för yrkeslivet, individen och/eller samhället, nu och i framtiden. Svaret på den didaktiska varför-frågan får konsekvenser för svaren på vad- och hur-frågorna.

\section{Integrativ didaktik}

Detta analysområde handlar om interdisciplinära läroplansmål, såsom bildning, demokrati och hållbar utveckling (Belova m.fl., 2017). För naturvetenskapsämnena finns en hel del skrivet kring undervisning och lärande för hållbar utveckling (se t.ex. Burmeister, Rauch \& Eilks, 2012; Sjöström, 2018b). I Jakobson, Lundegård och Wickman (2014) finns kapitel om exempelvis kroppsliggörande undervisning, estetik, genusdidaktik, moral och etik i undervisningen och om identitetsutveckling i samtal om hållbar utveckling. Det finns även böcker som tar ett helhetsgrepp genom att bygga hela undervisningen kring kritiska hållbarhetsperspektiv (t.ex. Hodson, 2011). Generellt handlar integrativ didaktik om att rama in undervisning och lärande med värdegrundsperspektiv.

\section{Didaktisk modellering}

Detta analysområde handlar om undervisningsutvecklande (ämnes)didaktisk forskning baserad på så kallad didaktisk modellering. Didaktiska modeller kan användas både som analysredskap och som verktyg vid planering och genomförande av undervisning (Uljens, 1997; Jank \& Meyer, 2006; Krogh m.fl., 2016). Väl utarbetade modeller stärker även lärares kompetens att göra välövervägda didaktiska val. I någon mening sysslar varje lärare med didaktisk modellering, om än oftast tämligen omedvetet. För att medvetandegöra det kan man ta hjälp av vetenskapligt grundade didaktiska modeller, såsom organiserande syften (Wickman \& Ligozat, 2011), didaktiska dilemman (Rydberg, 2018), språkliga samspel (Olander, 2010) och bedömning för lärande (Wiliam, 2009). Alla exemplen har potential att förändra praktiken, men praktiken kommer även att påverka modellerna. Detta samspel mellan 
teori och praktik benämner Ingerman och Wickman (2015) didaktisk modellering. Med denna tonas alltså distinktionen mellan teori och praktik ner.

För naturvetenskapsämnena har Fischler (2011) diskuterat didaktisk modellering baserat på Klafkis idéer om bildning och didaktik. Mer konkret och ämnesnära beskriver Andersson (2011, se särskilt s. 160) en modell för design av undervisning i naturvetenskapliga ämnen. Den bygger bland annat på hans tankar kring "innehållsorienterade teorier" (Andersson, 2006). Ett annat exempel är en didaktisk modell för socio- och problemorienterad undervisning i naturvetenskapliga ämnen, som Marks och Eilks (2009) har utformat.

Fritzell och Fritzén (2007) diskuterar två olika sätt att se på förhållandet mellan teori och praktik inom utbildningsvetenskaplig forskning. Det ena är ett instrumentellt förhållningssätt där effektiva undervisningsmetoder ska implementeras. Det andra är ett reflexivt förhållningssätt med betoning på analys och reflektion. Det är huvudsakligen det senare - ett kritiskt-hermeneutiskt förhållningssätt - som lyfts fram i denna artikel.

En viktig uppgift för didaktisk forskning är att systematisera och problematisera den omfattande beprövade erfarenhet som yrkesverksamma lärare besitter. I nästa steg gäller det alltså att i samspel med lärare stödja dem i att arbeta med didaktisk teori och didaktisk modellering. Hansén och Sjöberg (2006, s. 267) skriver: "Didaktiska teorier anger [...] riktningen enligt vilken undervisningen utvecklas, samtidigt som teorierna hjälper lärarna att bli medvetna om, genomskåda och även frigöra sig från rutiner [...] Den teoretiska reflektionen över praxis kan därmed bidra till att utveckla och förändra praxis."

I linje med detta skriver Uljens (1997, s. 9): "Didaktiska teorier och modeller är viktiga instrument med vilkas hjälp läraren kan hantera sin verklighet begreppsligt och därmed utveckla sin verksamhet. Ett huvudsakligt syfte med den vetenskapligt baserade lärarutbildningen är därför att ge blivande och verksamma lärare möjlighet att utveckla sitt personliga didaktiska tänkande och handlande med utgångspunkt i didaktiska teorier och modeller" Nilholm (2016). framhäver att didaktiska teorier är centrala i en lärarutbildning och dess examensarbeten, "eftersom de didaktiska frågorna, när de ställs utifrån skolans breda uppdrag, fångar in de väsentligaste aspekterna av lärares arbete" (s. 67). Han betonar vikten av professionsrelevant forskning och ger förslag på tre olika ämnesdidaktiska inriktningar på examensarbeten: (a) analys av ämneskonceptioner, (b) gestaltad didaktik (hur undervisas ämnet ute i skolorna?) och (c) utprovning av didaktiska arbetssätt. I en nyligen utgi- 
ven bok redigerad av Carlgren (2017) diskuteras undervisningsutvecklande forskning baserad på så kallade Learning Studies.

\section{Avslutande tankar kring professionsdidaktik för blivande lärare}

Genom integrativa lärarprofessionsämnen skapas en relevant helhet för blivande lärare. Det är ämnen avsedda att utveckla hela det spektrum av kunskaper (inkl. skolrelevanta ämneskunskaper) som en lärare behöver. Didaktik är namnet både på lärares praxiskunskap och på deras professionsvetenskap. En central del av didaktiken är ämnesdidaktik för den blivande lärarens undervisningsämnen. I ämnesdidaktiken (i bred bemärkelse) möts ämneskunskap (kunskaper i och om ämnet), utbildningsvetenskaplig teori och beprövad erfarenhet. Här har jag särskilt betonat vikten av forskningsbasering och särskilt kritisk-hermeneutiska perspektiv. Jag har betonat relevans och mina resonemang har lett fram till ett ramverk med tio analysområden. Lärarprofessionsämnena vid Malmö universitet har ett pågående utvecklingsarbete som bland annat tar sin utgångspunkt i ramverket.

Analysområdena i ramverket pekar på ämnesdidaktiska områden där det kan finnas behov av ytterligare forskning. För att möjliggöra både forskningsbaserade lärarprofessionsämnen och utveckling av den ämnesdidaktiska forskningen behöver det finnas levande didaktiska forskningsmiljöer vid lärosäten med lärarutbildning. Didaktikforskning görs för lärare (och lärarutbildning) och utförs oftast av lärarutbildade forskare. Många gånger görs den med lärare i praxisnära forskningsprojekt, exempelvis genom didaktisk modellering. Utgångspunkten är lärarnas behov, både de behov som de själva upplever och de behov som didaktikforskarna får syn på i mötet med praktiken.

Utöver forskningsbasering och betoning av professionsrelevans, är även den utbildningsfilosofiska och läroplansteoretiska inramningen av central betydelse. Gunnar Bergendal, som var rektor för Lärarhögskolan i Malmö under åren 1973-1995, betonade bildning som ett viktigt mål för lärarutbildningarna (Rudvall, 1995). Även om det är ett långt ifrån entydigt begrepp (Sjöström m.fl., 2017), menar jag att det är dags att återuppväcka denna målbild och låta den förenas med idéerna kring akademiska lärarprofessionsämnen, som alltså Malmö universitet nu arbetat med i snart $20 \stackrel{a}{\text { àr }}$.

Utifrån Klafkis tänkande är bildnings- och didaktikbegreppen mycket nära relaterade till varandra (Fischler, 2011; Vásquez-Levy, 2002). Dessutom 
rör det sig om ett kritiskt-hermeneutiskt bildningsbegrepp inramat av epoktypiska nyckelproblem, såsom globala utmaningar. I figur 2 lyfter jag fram några nyckelbegrepp som beskriver min vision för (ämnes)didaktik i integrativa lärarprofessionsämnen. Fokus är på (utveckling av) ämnes- och forskningsreflekterad didaktisk praktik, alltså på den yta i mitten där de tre cirklarna överlappar varandra. Jämfört med figur 1 täcker de tre cirklarna i figur 2 ett totalt sett mindre kunskaps- och praktikområde (exempelvis är didaktik en del av utbildningsvetenskap), men i båda figurerna är ämnesdidaktisk praxis i centrum.

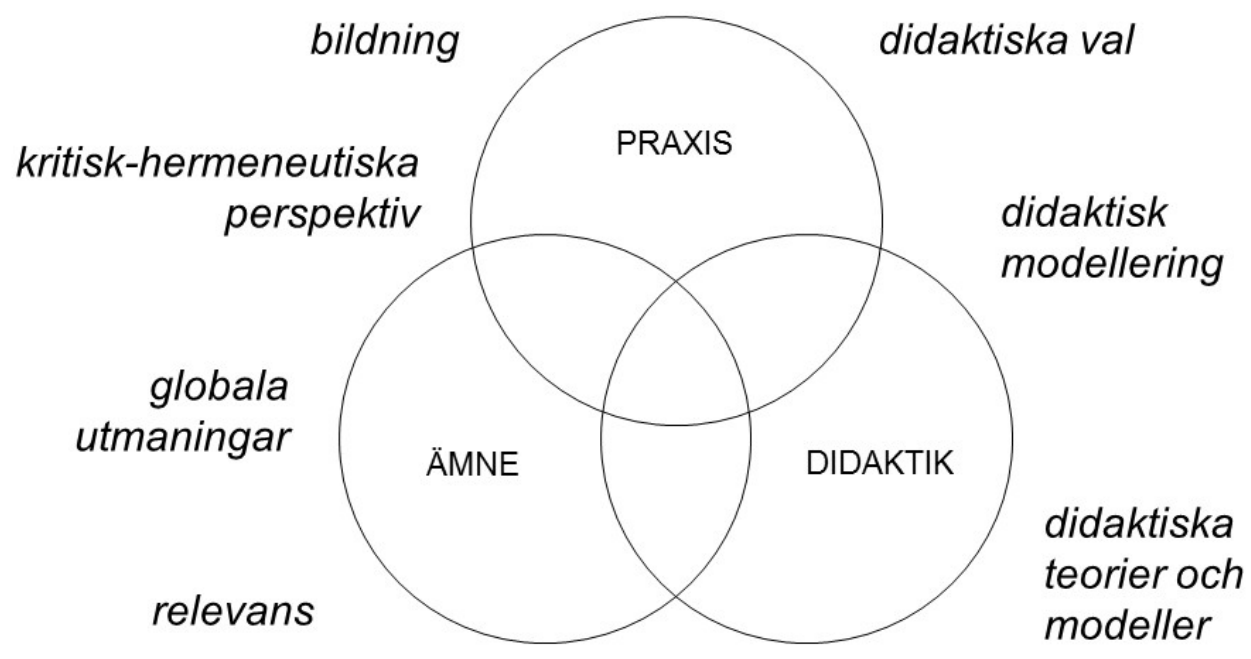

Figur 2. Några nyckelbegrepp för att beskriva artikelns syn på (ämnes)didaktik $i$ integrativa lärarprofessionsämnen. I centrum är (utveckling av) ämnesdidaktisk praxis.

Avslutningsvis vill jag kommentera de krav som införandet av integrativa lärarprofessionsämnen kommer att ställa på lärarutbildarnas kompetens. Jag menar att den optimala lärarutbildaren själv har lärarutbildning och omfattande erfarenhet av undervisning i ämnet för aktuellt stadium, fördjupade skolrelevanta ämneskunskaper (i och om ämnet) och utbildningsvetenskaplig forskarutbildning med för professionsämnet relevant inriktning. Få personer uppfyller alla dessa krav. Därför behöver lärarutbildningarna lärarlag som tillsammans uppfyller kraven. Men för att åstadkomma integrering behöver mycket arbete, tid och fokus läggas på gemensam utveckling av de integrativa lärarprofessionsämnena och, som en del av denna process, även på omfattande fortbildning av lärarutbildarna inom de områden där de har mindre utvecklade kunskaper och erfarenheter. 
Med integrativa lärarprofessionsämnen kan den "pedagogiska, allmändidaktiska, ämnesdidaktiska, ämnesmässiga och praktiska kompetensen [... fås att] smälta samman till en integrerad del av lärarens personlighet" (Sjöholm m.fl., 2017, s. 64).

\section{Acknowledgement}

Denna artikel har skrivits i anslutning till ett programutvecklingsuppdrag vid Fakulteten för lärande och samhälle vid Malmö universitet. Uppdragets titel var "Integrerad utbildningsvetenskap (uvk) i ämneslärarutbildningens förstaämnen samt ämnesdidaktik i samtliga ämnen" (Dnr UTB 3.2.2-2017/45). Jag vill särskilt tacka utbildningsledare Gunilla Löfström och universitetslektor Bo Lundahl för ett konstruktivt samarbete kring uppdraget och för era synpunkter på tidigare versioner av artikeln. Tack även till två anonyma granskare och till docent Clas Olander med flera för stimulerande samtal om (ämnes)didaktikens karaktär och gränser.

\section{Referenser}

Aikenhead, G. S. (2003). Chemistry and physics instruction: integration, ideologies, and choices. Chemistry Education Research and Practice, 4, 115-130.

Almqvist, J. (2016). "Didaktik och ämnesdidaktik - exemplet Uppsala universitet", PM, Uppsala, 2016-02-08.

Andersson, B. (2006). Innehållsorienterande teorier och design av undervisning - en ny möjlighet till kunskapsbygge i lärarutbildningen. Med exempel från naturvetenskap. I: S. Ongstad (red.), Fag og didaktikk i lærerutdanning - Kunnskap i grenseland, s. 207-223. Oslo: Universitetsforlaget.

Andersson, B. (2008a). Grundskolans naturvetenskap - Helhetssyn, innehåll och progression. Lund: Studentlitteratur.

Andersson, B. (2008b). Att förstå skolans naturvetenskap - Forskningsresultat och nya idéer. Lund: Studentlitteratur.

Andersson, B. (2011). Att utveckla undervisning i naturvetenskap - kunskapsbygge med hjälp av ämnesdidaktik, Lund: Studentlitteratur.

Areskoug, M., Ekborg, M., Lindahl, B. \& Rosberg, M. (2013). Naturvetenskapens bärande idéer - för lärare F-6. Malmö: Gleerups.

Areskoug, M., Ekborg, M., Nilsson, K. \& Sallnäs, D. (2015). Naturvetenskapens bärande idéer i praktiken - metodik för lärare F-6. Malmö: Gleerups.

Avraamidou, L. (2014). Studying science teacher identity: current insights and future research directions. Studies in Science Education, 50, 145-179.

Belova, N., Dittmar, J., Hansson, L., Hofstein, A., Nielsen, J. A., Sjöström, J., \& Eilks, I. (2017). Cross-curricular goals and raising the relevance of science education. In: K. Hahl, K. Juuti, J. Lampiselkä, J. Lavonen \& A. Uitto (eds.), Cognitive and affective aspects in science education research, s. 297-307. Dordrecht: Springer.

Bencze, L. \& Alsop, S. (eds.) (2014). Activist science and technology education. Dordrecht: Springer. 
Bentley, P.-O. \& Bentley, C. (2016). Milstolpar och fallgropar i matematikinlärningen - Matematikdidaktisk teori om misstag, orsaker och åtgärder. Stockholm: Liber.

Berry, A., Friedrichsen, P. \& Loughran, J. (eds.) (2015). Re-examining pedagogical content knowledge in science education. Routledge.

Birkeland, N. R. (2010). Analogi: Perspektiver på Klafkis didaktikk. I: J. Midtsundstad \& I. Willbergh (red.), Didaktikk - nye teoretiske perspektiver på undervisning (s. 63-75). Cappelen Akademisk Forlag.

Brante, G. (2016). Allmän didaktik och ämnesdidaktik - en inledande diskussion kring gränser och anspråk. Nordisk Tidskrift för Allmän Didaktik, 2, 52-68.

Brantefors, L. (2016). "Ämnesdidaktik och lärarutbildning - ett diskussionsunderlag om ämnesdidaktik, ämnesdidaktisk forskning och lärarutbildning", PM, Uppsala, 201603-29.

Bronäs, A. \& Runebou, N. (2016). Ämnesdidaktik - en undervisningskonst, uppl. 2:1. Lund: Studentlitteratur.

Burmeister, M., Rauch, F., \& Eilks, I. (2012). Education for Sustainable Development (ESD) and chemistry education. Chemistry Education Research and Practice, 13, 59-68.

Carlgren, I. (red.) (2017). Undervisningsutvecklande forskning - exemplet Learning study. Malmö: Gleerups.

Dawson, E. (2014). Equity in informal science education: developing an access and equity framework for science museums and science centres. Studies in Science Education, 50, 209-247.

Ekborg, M., Ideland, M., Malmberg, C., Ottander, C. \& Rosberg, M. (2016). Samhällsfrågor i det naturvetenskapliga klassrummet. 2:a uppl., Malmö: Gleerups.

Ekendahl, I., Nohagen, L. \& Sandahl, J. (2015). Undervisa i samhällskunskap - en ämnesdidaktisk introduktion. Stockholm: Liber.

Englund, T. (1997). Undervisning som meningserbjudande. I: M. Uljens (red.), Didaktik teori, reflektion och praktik, s. 120-145. Lund: Studentlitteratur.

Englund, T. (2007). Om relevansen av begreppet didaktik. Acta Didactica Norge, 02.10.2007.

Fischler, H. (2011). Didaktik - an appropriate framework for the professional work of science teachers? In: D. Corrigan, J. Dillon \& R. Gunstone (eds.), The professional knowledge base of science teaching, s. 31-50. Dordrecht: Springer.

Fritzell, C. \& Fritzén, L. (red.) (2007). Integrativ didaktik i olika ämnesperspektiv, Växjö University Press.

Graf, S. T. (2017). Dannende undervisning - en begrebsafklaring. Studier i læreruddannelse og -profession, 2, 6-29.

Gundem, B. B. (2008). Didaktikk - fagdidaktikk, anstrengte eller fruktbare forhold? Acta Didactica Norge, Vol. 2, Nr. 1, Art. 1.

Hansén, S-E. \& Forsman, L. (red.) (2017). Allmändidaktik - vetenskap för lärare. 2:a uppl., Lund: Studentlitteratur.

Hansén, S-E. \& Sjöberg, J. (2006). Didaktik i lärarutbildningar. I: S. Ongstad (red.), Fag og didaktikk i lærerutdanning - Kunnskap i grenseland, s. 258-273. Oslo: Universitetsforlaget.

Hermansson Adler, M. (2009). Historieundervisningens byggstenar - grundläggande pedagogik och ämnesdidaktik. Stockholm: Liber.

Hodson, D. (2008). Towards scientific literacy - A teachers' guide to the history, philosophy and sociology of science. Rotterdam: Sense.

Hodson, D. (2011). Looking to the future: Building a curriculum for social activism. Rotterdam: Sense.

Holmberg, O. (2008). En berättelse om lärarutbildningen i Malmö. Rapporter om utbildning, 1/2008, Malmö högskola.

Hopmann, S. (1997). Wolfgang Klafki och den tyska didaktiken. I M. Uljens (red.), Didaktik - teori, reflektion och praktik, s. 198-214. Lund: Studentlitteratur. 
Hultén, M. (2008). Naturens kanon - formering och förändring av innehållet $i$ folkskolans och grundskolans naturvetenskap 1842-2007. Doktorsavhandling, Stockholms universitet.

Ingerman, $\AA$. \& Wickman, P.-O. (2015). Towards a teachers' professional discipline: Shared responsibility for didactic models in research and practice. In: P. Burnard, B.-M. Apelgren \& N. Cabaroglu (eds.), Transformative teacher research: theory and practice for the C21st, s. 167-179. Rotterdam: Sense.

Jakobsson, B., Lundegård, I. \& Wickman. P.-O. (2014). Lärande $i$ handling - en pragmatisk didaktik, Lund: Studentlitteratur.

Jank, W. (2014). Didaktik, Bildung, Content - on the writings of Frede V. Nielsen. Philosophy of Music Education Review, 22, 113-131.

Jank, W. \& Meyer, H. (1997). Del I: Didaktik och undervisning - didaktiska teorier i lärarens arbete. I: M. Uljens (red.), Didaktik - teori, reflektion och praktik, s. 15-74. Lund: Studentlitteratur.

Jank, W. \& Meyer, H. (2006). Didaktiske modeller. København: Hans Reitzels Forlag.

Jensen, B. E. (2006). Historiebrugsdidaktik - om at etablere en ny slags historiedidaktik. I: S. Ongstad (red.), Fag og didaktikk i lærerutdanning - Kunnskap i grenseland, s. 85-99. Oslo: Universitetsforlaget.

Jidesjö, A., Oscarsson, M., Karlsson, K. G. \& Strömdahl, H. (2009). Science for all or science for some: What Swedish students want to learn about in secondary science and technology and their opinions on science lessons. Nordina - Nordic Studies in Science Education, 5, 213-229.

Kansanen, P. (2009). Subject-matter didactics as a central knowledge base for teachers, or should it be called pedagogical content knowledge? Pedagogy, Culture E Society, 17, 29-39.

Kemp, P. (2005). Verdensborgeren som pædagogisk ideal: Pædagogisk filosofi for det 21. århundrede. København: Hans Reitzels Forlag.

King, D. (2012). New perspectives on context-based chemistry education: Using a dialectical sociocultural approach to view teaching and learning. Studies in Science Education, 48, 51-87.

Klafki, W. (1997). Kritisk-konstruktiv didaktik. I: M. Uljens (red.), Didaktik - teori, reflektion och praktik, s. 215-228. Lund: Studentlitteratur.

Klafki, W. (2000). The significance of classical theories of Bildung for a contemporary concept of Allgemeinbildung. In: I. Westbury, S. Hopmann \& K. Riquarts (eds.), Teaching as a reflective practice: the German Didaktik tradition, s. 85-108. Mahwah: Lawrence Erlbaum.

Krogh, E., Qvortrup, A. \& Spanget Christensen, T. (2016). Almendidaktik og fagdidaktik. Frederiksberg: Frydenlund.

Larsson, H. (2016). Idrott och hälsa - i går, i dag, i morgon. Stockholm: Liber.

Ligozat, F., Amade-Escot, C., \& Östman, L. (2015). Beyond subject specific approaches of teaching and learning: Comparative didactics. Interchange, 46, 313-321.

Lindahl, B. (2003). Lust att lära naturvetenskap och teknik?: en longitudinell studie om vägen till gymnasiet. Doktorsavhandling, Göteborgs universitet.

Malmgren, G. \& Thavenius, J. (1991). Svenskämnet i förvandling: historiska perspektiv-aktuella utmaningar. Lund: Studentlitteratur.

Marks, R. \& Eilks, I. (2009). Promoting scientific literacy using a socio-critical and problem-oriented approach to chemistry teaching: concept, examples, experiences. International Journal of Environmental and Science Education, 4, 131-145.

McClune, B., \& Jarman, R. (2012). Encouraging and equipping students to engage critically with science in the news: what can we learn from the literature?. Studies in Science Education, 48, 1-49.

McComas, W. F. (2017). Understanding how science works: the nature of science as the foundation for science teaching and learning. School Science Review, 98, 71-76. 
Midtsundstad, J. \& Willbergh, I. (red.) (2010). Didaktikk-nye teoretiske perspektiver på undervisning. Cappelen Akademisk Forlag.

Nielsen, F. V. (2011). Sammenlignende fagdidaktik: Genstandsfelt, perspektiver og dimensioner. I: E. Krogh \& F. Nielsen (red.), Sammenlignende fagdidaktik, Cursiv 7, s. 11-32.

Nilholm, C. (2016). Teori i examensarbetet - en vägledning för lärarstudenter. Lund: Studentlitteratur.

Olander, C. (2010). Towards an interlanguage of biological evolution: Exploring students' talk and writing as an arena for sense-making. Doktorsavhandling, Göteborgs universitet.

Ongstad, S. (red.) (2006). Fag og didaktikk i lærerutdanning - kunnskap i grenseland. Oslo: Universitetsforlaget.

Pedretti, E., Bencze, L., Hewitt, J., Romkey, L. \& Jivraj, A. (2008). Promoting issues-based STSE perspectives in science teacher education: problems of identity and ideology. Science E Education, 17, 941-960.

Pedretti, E. \& Nazir, J. (2011). Currents in STSE education: Mapping a complex field, 40 years on. Science Education, 95, 601-626.

Rudvall, G. (red.) (1995). Bildning, kunskap, demokrati - En vänbok till Gunnar Bergendal. Studentlitteratur: Lund.

Rydberg, C. (2018). Didaktiska dilemman i undervisning utifrån samhällsdilemman. Licentiatuppsats, Malmö universitet.

Sandell, K., Öhman, J. \& Östman, L. (2003). Miljödidaktik - naturen, skolan och demokratin. Lund: Studentlitteratur.

Scott, P., Mortimer, E. \& Ametller, J. (2011). Pedagogical link-making: A fundamental aspect of teaching and learning scientific conceptual knowledge. Studies in Science Education, 47, 3-36.

Shulman, L. S. (1987). Knowledge and teaching: foundations of the new reform. Harvard Educational Review, 57, 1-22.

Sismondo, S. (2009). An introduction to Science and Technology Studies. 2nd ed., Wiley-Blackwell.

Sjøberg, S. (2010). Naturvetenskap som allmänbildning - en kritisk ämnesdidaktik. 3:e uppl., Lund: Studentlitteratur.

Sjöholm, K., Kansanen, P., Hansén, S.-E. \& Kroksmark, T. (2017). Ämnesdidaktik - en integrerad del av allmändidaktik. I S.-E. Hansén \& L. Forsman, L. (red.), Allmändidaktik vetenskap för lärare, s. 49-66. Lund: Studentlitteratur.

Sjöström, J. (2006a). Fysikifierat och biofierat. Kemivärlden Biotech med Kemisk Tidskrift, nr. $1 / 2006$, s. 22-24.

Sjöström, J. (2006b). Beyond classical chemistry: subfields and metafields of the molecular sciences. Chemistry International, Vol. 28, No. 5, s. 9-15.

Sjöström, J. (2007). The discourse of chemistry (and beyond). HYLE - International Journal for Philosophy of Chemistry, 13, 83-97.

Sjöström, J. (2016). "Allmän ämnesdidaktik - vad är det och varför behövs en sådan metanivå?", muntlig presentation vid den svenska ämnesdidaktiska konferensen NÄD, april 2016 i Malmö.

Sjöström, J. (2017). "General subject didactics - core knowledge and perspectives", muntlig presentation vid den nordiska ämnesdidaktiska konferensen NoFA, maj 2017 i Odense.

Sjöström, J. (2018a, under tryckning). Bildning som didaktisk ledstjärna. I: E. Insulander \& S. Selander (red.), Att bli lärare, Stockholm: Liber.

Sjöström, J. (2018b). Science teacher identity and eco-transformation of science education: comparing Western modernism with Confucianism and reflexive Bildung. Cultural Studies of Science Education, 13, 147-161. 
Sjöström, J. \& Eilks, I. (2018). Reconsidering different visions of scientific literacy and science education based on the concept of Bildung. In: J. Dori, Z. Mevarech, \& D. Baker (eds.), Cognition, metacognition, and culture in STEM education, s. 65-88. Dordrecht: Springer.

Sjöström, J., Frerichs, N., Zuin, V. G. \& Eilks, I. (2017). Use of the concept of Bildung in the international science education literature, its potential, and implications for teaching and learning. Studies in Science Education, 53, 165-192.

Sjöström, J. \& Talanquer, V. (2018). Eco-reflexive chemical thinking and action, Current Opinion in Green and Sustainable Chemistry, 13, 16-20.

Steffensen, B. (2003). Det fagdidaktiske projekt-almen fagdidaktik set i lyset af viden, dannelse og læring. København: Akademisk Forlag.

Stuckey, M., Hofstein, A., Mamlok-Naaman, R. \& Eilks, I. (2013). The meaning of 'relevance' in science education and its implications for the science curriculum. Studies in Science Education, 49, 1-34.

Sund, P. (2014). Att välja undervisningsinnehåll. I: B. Jakobsson, I. Lundegård \& P.-O. Wickman (red.), Lärande i handling - en pragmatisk didaktik, s. 47-57, Lund: Studentlitteratur.

Sund, P. \& Sund, L. (2017). Hållbar utveckling - ämnesdidaktisk tematisering för grundskolan. Stockholm: Liber.

Talanquer, V. (2018). Progressions in reasoning about structure-property relationships. Chemistry Education Research and Practice. doi: 10.1039/C7RP00187H, published online 13 Oct 2017.

Tyson, R. (2017a). "En skola för bildning kräver synliggörande av lärares didaktiska arbete", Skola \& Samhälle, publicerad online 9 februari, 2017.

Tyson, R. (2017b). The rough ground. Narrative explorations of vocational Bildung and wisdom in practice. Doktorsavhandling, Stockholms universitet.

Uljens, M. (red.) (1997). Didaktik - teori, reflektion och praktik. Lund: Studentlitteratur.

Vásquez-Levy, D. (2002). Bildung-centred Didaktik: a framework for examining the educational potential of subject matter. Journal of Curriculum Studies, 34, 117-128.

Wahlström, N. (2015). Läroplansteori och didaktik. Malmö: Gleerups.

Wello Westlin, A. (2000). Samhällsorienteringens didaktik. I: C. A. Säfström \& P. O. Svedner (red.), Didaktik - perspektiv och problem, s. 77-92, Lund: Studentlitteratur.

Wickman, P. O. (2012). Using pragmatism to develop didactics in Sweden. Zeitschrift für Erziehungswissenschaft, 15, 483-501.

Wickman, P.-O. \& Ligozat, F. (2011). Scientific literacy as action: consequences for content progression. In: C. Linder, L. Östman, D. A. Roberts, P.-O. Wickman, G. Erickson \& A. MacKinnon (eds.), Exploring the landscape of scientific literacy, s. 145-159. New York: Routledge.

Wickman, P.-O. \& Persson, H. (2015). Naturvetenskap och naturorienterande ämnen i grundskolan - en ämnesdidaktisk vägledning. 2:a uppl., Stockholm: Liber.

Wiliam, D. (2009). Assessment for learning: why, what and how?. London: Institute of Education, University of London.

Öhman, J. (2014). Om didaktikens möjligheter. Ett pragmatiskt perspektiv. Utbildning $\mathcal{E}$ Demokrati, 23, 33-52.

Östman, L. (2014). Värden och följemeningar. I: B. Jakobsson, I. Lundegård \& P.-O. Wickman (red.), Lärande i handling - en pragmatisk didaktik, s. 25-35, Lund: Studentlitteratur. 